Терапевтична стоматологія

УДК 616.314.17-008.1-036.12+616.516]-08-036.8

DOI

(C). В. Єлісєєва

Харківський національний медичний університет

\title{
Оцінка специфічного імунітету порожнини рота при комплексному лікуванні пацієнтів із генералізованим пародонтитом на тлі червоного плоского лишаю
}

Резюме. Було вивчено стан імунітету ротової порожнини у пацієнтів із хронічним генералізованим пародонтитом на тлі червоного плоского лишаю як одного із можливих об'єктивних критеріїв якості лікування. Успішне лікування хворих за розробленою нами схемою (лізомукоїд, лісобакт, лізоцимумісний гель) супроводжується відновленням показника місцевого специфічного імунітету ротової порожнини sIgA як безпосередньо після закінчення курсу, так і через 3 місяці після завершення терапії.

Ключові слова: хронічний генералізований пародонтит, червоний плоский лишай, місцевий імунітет, лізоцимуміщувальні засоби.

\section{О. В. Елисеева}

Харьковский национальный медицинский университет

\section{Оценка специфического иммунитета полости рта при комплексном лечении пациентов с хроническим генерализованным пародонтитом на фоне красного плоского лишая}

Резюме. Было изучено состояние иммунитета полости рта у пациентов с ХГП на фоне красного плоского лишая как одного из возможных объективных критериев качества лечения. Успешное лечение больных по разработанной нами схеме (лизомукоид, лисобакт, лизоцимсодержащий гель) сопровождается восстановлением показателя местного специфического иммунитета полости рта sIgA как непосредственно после окончания курса, так через 3 месяца после завершения терапии.

Ключевые слова: хронический генерализованный пародонтит, красный плоский лишай, местный иммунитет, лизоцимсодержащие средства.

\section{o.v. Yelisieyeva}

Kharkiv National Medical University

\section{Evaluation of specific immunity of oral cavity of comprehensive treatment of patients with chronic generalized periodontitis associated with oral lichen planus}

Summary. The state of the oral cavity immunity of the patients with chronicle generalized periodontitis together with oral lichen planus has been examined as one of the possible objective criterion of the treatment quality. Successful treatment of the patients according to the worked out scheme (lizomukoid, lisobakt, lysozyme containing gel) is accompanied by restoration of the local specific immunity characteristics of the oral cavity sIgA level normalization just after the end of the course of treatment and in 3 months after the therapy.

Key words: chronicle generalized periodontitis, oral lichen planus, local immunity characteristics, lysozyme containing medicine. 
Вступ. Зміни слизової оболонки порожнини рота (СОПР) та тканин пародонта найчастіше $€$ першими клінічними, а іноді й єдиними ознаками порушень функціонування різних органів і систем. Разом з тим, порушення, що виникають у порожнині рота, можуть збільшувати тяжкість фонового захворювання. Червоний плоский лишай (ЧПЛ) - одне з найпоширеніших і маніфестних за клінічними проявами захворювань СоПР. У цей час спостерігається стійкий ріст сполучного перебігу хронічного генералізованого пародонтиту (ХГП) та ЧПЛ, за даними різних авторів, ХГП у пацієнтів із ЧПЛ зустрічається більш ніж у 80 \% випадків $[1,3,6]$. Лікування поєднаного перебігу ХГП та ЧПЛ являє значні труднощі та $є$ не до кінця розробленою процедурою, тому не тільки розробка ефективних способів лікування, а i розробка способів оцінки ефективності лікувальних заходів $є$ актуальним завданням практичної стоматології.

Метою дослідження стало визначення в ротовій рідині sIgA, як показника специфічного імунітету, в пацієнтів із ХГП і ЧПЛ до лікування й після його закінчення та показника позитивного впливу запропонованої комплексної терапії на імунологічну ланку патогенезу ХГП.

Матеріали і методи. Було обстежено 72 пацієнти, яких поділили на 4 групи. В 1 групу (20 осіб) увійшли пацієнти із ХГП початкового і легкого ступенів тяжкості без ЧПЛ. 32 хворих із поєднаним перебігом ХГП (початковий і легкий ступені тяжкості) на тлі ЧПЛ (типова форма) поділили на дві групи (2 і 3). 2 групу (16 осіб) увійшли пацієнти із ХГП і ЧПЛ без ураження СОПР, а в 3 групу (16 осіб) - з ураженням СОПР. Контрольну 4 групу склали пацієнти 3 інтактним пародонтом (20 осіб). За способом лікування групи 2 і 3 поділили на підгрупи 2a, 2б, За, Зб (по 8 осіб у кожній).

Пацієнтам груп 1, 2а й 3а призначали ополіскувач «Perio-Aid» 0,12 \% («Dentaid», Іспанія) 2 рази на день, після процедури чищення зубів пастою «Лакалут актив» (Німеччина). Пацієнтам За групи радили обліпихову олію на вогнища ураження СОПР - від 8 до 10 процедур на курс. Таким чином, пацієнти 1, 2а й За груп отримували стандартну терапію. Для пацієнтів 2б і Зб груп ми розробили нову схему лікування, що включала зубний еліксир «Лізомукоїд» (НВА «Одеська біотехнологія, Україна), зубну пасту «Лакалут актив» (Німеччина) й антисептичні таблетки «Лісобакт» (Босналек д.Д., Боснія й Герцеговина). У лікувальну схему $3 б$ групи також були включені лізоцимумісний гель (НВА «Одеська біотехнологія, Україна) на вогнища ураження СОПР і крайовий пародонт.

Системна терапія ЧПЛ (після консультації фахівця) включала призначення пацієнтам 2 і 3 груп делагілу по 1 таблетці 2 рази на день, ксантинол нікотинату по 1 таблетці 3 рази на день і вітаміну Е в капсулах по 1 капсулі 1 раз на день.

Імунологічне дослідження ротової рідини включало визначення sIgA за допомогою імуноферментного аналізу $[4,5]$.

Для статистичної обробки даних використовували пакет програм обробки даних загального призначення Statistica for Windows версії 6.0 [2].

Результати досліджень та обговорення. Ефективність лікування пацієнтів різних груп оцінювали шляхом вивчення показника місцевого специфічного імунітету порожнини рота SIgA.

У всіх пацієнтів із ХГП на тлі ЧПЛ у ротовій рідині відзначено підвищення в 2 рази (порівняно 3 нормою) концентрації sIgA (табл.), а в пацієнтів 1 групи цей показник мав тенденцію до різкого зниження. Після проведеного лікування за розробленою нами схемою відбулася нормалізація рівня sIgA у ротовій рідині пацієнтів 2б і Зб груп протягом усього періоду спостереження. У хворих із ХГП на тлі ЧПЛ, яких лікували за стандартною схемою (2а й 3a), достовірні зміни даного показника відсутні, а в пацієнтів 1 групи рівень sIgA нор-

таблищя. Уміст SIgA у ротовій рідині в обстежених пацієнтів (г/л)

\begin{tabular}{|c|c|c|c|}
\hline Група & До лікування & Через 14 днів після лікування & Через 3 місяці після лікування \\
\hline $1(\mathrm{n}=20)$ & $0,13 \pm 0,05^{*}$ & $0,31 \pm 0,05$ & $0,17 \pm 0,03^{*}$ \\
\hline $2 \mathrm{a}(\mathrm{n}=8)$ & $0,54 \pm 0,03^{*}$ & $0,45 \pm 0,05^{*}$ & $0,49 \pm 0,12^{*}$ \\
\hline $26(\mathrm{n}=8)$ & $0,60 \pm 0,08^{*}$ & $0,39 \pm 0,04$ & $0,35 \pm 0,04$ \\
\hline $3 \mathrm{a}(\mathrm{n}=8)$ & $0,60 \pm 0,07^{*}$ & $0,52 \pm 0,07 *$ & $0,48 \pm 0,06 *$ \\
\hline $36(\mathrm{n}=8)$ & $0,57 \pm 0,09^{*}$ & $0,36 \pm 0,03$ & $0,37 \pm 0,06$ \\
\hline $4(\mathrm{n}=20)$ & $0,29 \pm 0,05$ & - & - \\
\hline
\end{tabular}

Примітка. * - значення показника, порівняно з контролем, статистично вірогідне (p<0,05). 
малізувався безпосередньо після закінчення терапії, але при контрольному вимірі через 3 місяці повернувся до вихідного.

Висновки. На основі вищевикладеного можна зробити висновок, що ХГП, а також поєднаний перебіг ХГП і ЧПЛ, супроводжується істотними змінами показників місцевого імунітету ротової порожнини, які проявляються в зростанні у ротовій рідині рівня sIgA.

\section{Список літератури}

1. Белёва Н. С. Совершенствование диагностики и комплексного лечения в системе диспансеризации больных красным плоским лишаем слизистой оболочки полости рта : автореф. дисс. на соискание уч. степени канд. мед. наук / Н. С. Белёва. - Пермь, 2010. -23 c.

2. Гланц С. Медико-биологическая статистика / С. Гланц. - М. : Практика, 1999. - 459 с.

3. Грудянов А. И. Заболевания пародонта / А. И. Грудянов. - М. : Издательство «Медицинское информационное агентство", 2009. - 336 с.

4. Рабинович И. М. Коррекция микробиологических
Ефективність способу лікування хворих із ХГП на тлі ЧПЛ, розробленого нами, підтверджується відновленням показника місцевого специфічного імунітету порожнини рота SIgA як безпосередньо після закінчення курсу, так через 3 місяці після завершення терапії.

Нормалізація показників локального імунітету ротової порожнини супроводжується відсутністю симптомів запалення тканин пародонта.

изменений у больных с дисбактериозами полости рта / И. М. Рабинович, Н. А. Дмитриева, О. И. Ефимович : труды VI съезда Стоматологической ассоциации России. - М., 2000. - 281. - 283 с.

5. Шабанская М. А. Некоторые показатели дисбактериозов полости рта при разных формах стоматологических заболеваний и эффективность коррекционной бактериальной терапии : автореф. дисс. на соискание уч. степени канд. мед. наук. - M, 1994. - 23 с. 6. Sugerman P. B. Oral lichen planus: cause, diagnosis and management / P. B. Sugerman, N. W. Savage // Aust. Dent. J. - 2002. - Vol. 47. - P. 290-297. 